\title{
Characterization of a Highly Enriched Microbial Consortium Reductively Dechlorinating 2,3-Dichlorophenol and 2,4,6-Trichlorophenol and the Corresponding cprA Genes from River Sediment
}

\author{
WAEL S. EL-SAYED ${ }^{1,2 *}$ \\ ${ }^{1}$ Biology Department, Faculty of Science, Taibah University, Almadinah Almunawarah, KSA \\ ${ }^{2}$ Microbiology Department, Faculty of Science, Ain Shams University, Cairo, Egypt
}

Submitted 4 August 2015, revised 11 March 2016, accepted 22 March 2016

\begin{abstract}
Anaerobic reductive dechlorination of 2,3-dichlorophenol (2,3DCP) and 2,4,6-trichlorophenol (2,4,6 TCP) was investigated in microcosms from River Nile sediment. A stable sediment-free anaerobic microbial consortium reductively dechlorinating 2,3DCP and 2,4,6 TCP was established. Defined sediment-free cultures showing stable dechlorination were restricted to ortho chlorine when enriched with hydrogen as the electron donor, acetate as the carbon source, and either 2,3-DCP or 2,4,6-TCP as electron acceptors. When acetate, formate, or pyruvate were used as electron donors, dechlorination activity was lost. Only lactate can replace dihydrogen as an electron donor. However, the dechlorination potential was decreased after successive transfers. To reveal chlororespiring species, the microbial community structure of chlorophenol-reductive dechlorinating enrichment cultures was analyzed by PCR-denaturing gradient gel electrophoresis (DGGE) of 16S rRNA gene fragments. Eight dominant bacteria were detected in the dechlorinating microcosms including members of the genera Citrobacter, Geobacter, Pseudomonas, Desulfitobacterium, Desulfovibrio and Clostridium. Highly enriched dechlorinating cultures were dominated by four bacterial species belonging to the genera Pseudomonas, Desulfitobacterium, and Clostridium. Desulfitobacterium represented the major fraction in DGGE profiles indicating its importance in dechlorination activity, which was further confirmed by its absence resulting in complete loss of dechlorination. Reductive dechlorination was confirmed by the stoichiometric dechlorination of 2,3DCP and 2,4,6TCP to metabolites with less chloride groups and by the detection of chlorophenol RD cprA gene fragments in dechlorinating cultures. PCR amplified cprA gene fragments were cloned and sequenced and found to cluster with the cprA/pceA type genes of Dehalobacter restrictus.
\end{abstract}

Key words: 16S rDNA, chlorophenol, cprA gene, DGGE, reductive dechlorination

\section{Introduction}

Chlorinated phenols (CPs) are common chemical pollutants harmful to human health that are found in ground water due to unmanaged industrial discharges (WHO, 1998). Chlorinated phenols have been extensively used in the manufacture of pesticides, herbicides and dyes and are therefore commonly found in sediments, soil and water resources near industrial wastewater effluents (WHO, 1989; Takeuchi et al., 2000). Concern about these compounds relates directly to their high toxicity and persistence in a variety of habitats to levels exceeding natural limits. Chlorinated phenols tend to accumulate in anaerobic habitats, evading aerobic microorganisms that are able to degrade them (Villemur, 2013). The biodegradation of CPs in anaerobic environments has been extensively studied (Häggblom, 1992; McAllister et al., 1996; Masunaga et al., 1996). Recently, much attention has been focused on anaerobic bacteria that can dechlorinate chlorinated hydrocarbons in a unique process called reductive dechlorination (El Fantroussi et al., 1998; Holliger et al., 2003). Reductive dechlorination is driven by the activity of a class of enzymes called reductive dehalogenases (RDs). In this process, organohalide-respiring bacteria couple dechlorination to energy generation and growth using chlorinated hydrocarbons as electron acceptors (Holliger, et al., 1998; Smidt et al., 2000; Löffler et al., 2003; Smidt and de Vos, 2004). Dehalorespiring bacteria are found in soil, sediments, and wastewater sludge, and are able to dechlorinate different types of chloroorganics via a reductive dechlorination process (Häggblom and Bossert, 2003). However, many of these bacteria remain uncultured. Dehalorespiration was first reported by Deweed et al. (1990) in Desulfomonile tied$j e i$, an organism that couples reductive dechlorination

\footnotetext{
* Corresponding author: W.S. El-Sayed, Department of Biology, Faculty of Science, Taibah University, Almadinah Almunawwara, KSA; e-mail: waelsme@yahoo.com
} 
of 3-chlorobenzoate to formate oxidation. A number of dehalorespiring bacteria have since been described, however, those reducing chlorinated phenols are restricted to a few strains belonging to a few genera. A facultative anaerobic Myxobacterium, Anaeromyxobacter dehalogenans 2CP-1, has been described as a halorespiring bacteria reducing $2 \mathrm{CP}$ and 2,6-dichlorophenol (2,6DCP) (Cole et al., 1994; Sanford et al., 2002). In this case, dechlorination was found mostly to be site specific. Desulfovibrio dechloracetivorans SF3 showed ortho dechlorination of 2CP and 2,6DCP (Sun et al., 2000). The genus Desulfitobacteria was found to contain a relatively large number of strains capable of dechlorination of both aliphatic and aromatic hydrocarbons (Villemur et al., 2006). The first Desulfitobacterium strain, DCB-2, was isolated in 1992 (Madsen and Licht, 1992). Desulfitobacterium dehalogenans strain JW/IU-DC1, first documented by Utkin et al. (1994), was reported for its dechlorination of 2,3DCP, 2,6DCP, and 2,4,6TCP (Wiegel et al., 1999). Subsequently, other strains belonging to the genus Desulfitobacterium with dechlorination activity toward CPs were isolated and characterized, these included Desulfitobacterium chlororespirans strain Co23 (Sanford et al., 1996; Cupples et al., 2005), Desulfitobacterium hafniense strain DCB-2 (Christiansen and Ahring, 1996), strain TCP-A (Breitenstein et al., 2001), and strain PCP-1 (Bouchard et al., 1996; Villemur, 2013). The obligate anaerobic bacterium Dehalococcoides ethenogenes strain 195 known for its ability to dechlorinate tetrachloroethene (Maymo-Gatell et al., 1997) was recently reported to possess diverse dehalogenation ability. Genomic studies revealed the presence of 17 putative dehalogenase gene homologues in strain 195 that reflect its ability to dechlorinate different chlorinated aromatic hydrocarbons including different chlorophenol congeners (Fennell et al., 2004). Dehalogenation in the environment, particularly dechlorination activities in sedimentary environments, is an area of research interest due to its important ecological prospective (Häggblom and Bossert, 2003; Leys et al., 2013). Dechlorination of mono- and di-chlorophenol isomers in estuarine anaerobic sedimentary environments has been studied and chlorophenol-dechlorinating microbial communities in such environments have been characterized (Itoh et al., 2010). The sludge of related wastewater industrial effluents is a good candidate for studying reductive dechlorination of aryl halides. The dechlorination of pentachlorophenols was detected in the sludge from a pulp and paper mill (Karn et al., 2011). Reductive dechlorination of CPs, biphenyls, and benzenes has been reported in a number of sedimentary environments (Wu et al., 1998; Fagervold et al., 2005; Zanaroli et al., 2010; Kjellerup et al., 2014; Kuokkaa et al., 2014; Vandermeeren et al., 2014).
This study aims to assess whether the potential for microbial reductive dechlorination of aryl halides, such as CPs, exists in River Nile sediments and to characterize the bacterial community structure in reductive dechlorinating enrichment cultures developed for the establishment of a highly enriched bacterial consortium for reductive dechlorination of CPs.

\section{Experimental}

Materials and Methods

Sampling and anaerobic microcosms. Sediment samples were collected in 100-ml leak-proof stoppersupported screw-capped Duran bottles from the River Nile at active industrialized areas located in Helwan, Egypt $\left(29^{\circ} 51^{\prime} \mathrm{N}, 31^{\circ} 20^{\prime} \mathrm{E}\right)$. Sediment samples were spiked with 2,3DCP and 2,4,6-trichlorophenol (2,4,6TCP), flushed with hydrogen, and stored anaerobically in the dark for almost one year prior to use. Screening for dechlorinating bacteria was performed after the establishment of active microcosms and enrichment cultures. Microcosms were initiated by the addition of $10 \mathrm{~g}$ of sediment slurry into $90 \mathrm{ml}$ of basal mineral medium in $160 \mathrm{ml}$ serum bottles capped with Tefloncoated butyl rubber stoppers and sealed with aluminum caps. The head space was flushed with hydrogen gas. 2,3DCP and 2,4,6TCP were separately added to triplicate microcosms to a final concentration of $100 \mu \mathrm{M}$. Original unamended sediment slurry was used as a control. Microcosms were kept at room temperature for monitoring purposes at different time intervals.

Anaerobic enrichment cultures. Microcosms and anaerobic enrichment cultures were established using defined mineral salts medium containing (per liter): $\mathrm{NH}_{4} \mathrm{Cl}, 0.5 \mathrm{~g} ; \mathrm{K}_{2} \mathrm{HPO}_{4}, 0.4 \mathrm{~g} ; \mathrm{MgCl}_{2} \cdot 6 \mathrm{H}_{2} \mathrm{O}, 0.49 \mathrm{~g}$; $\mathrm{CaCl}_{2} \cdot 2 \mathrm{H}_{2} \mathrm{O}, 0.05 \mathrm{~g} ; \mathrm{KCl}, 0.052 \mathrm{~g}$; metal solution, $1 \mathrm{ml}$; vitamin solution, $20 \mathrm{ml}$. The metal solution had the following composition (per liter): $\mathrm{ZnSO}_{4} \cdot 7 \mathrm{H}_{2} \mathrm{O}$, $0.001 \mathrm{~g} ; \mathrm{CuSO}_{4} \cdot 5 \mathrm{H}_{2} \mathrm{O}, 0.002 \mathrm{~g} ; \mathrm{MnSO}_{4} \cdot 5 \mathrm{H}_{2} \mathrm{O}, 0.001 \mathrm{~g}$; $\mathrm{NaMoO}_{4} \cdot 2 \mathrm{H}_{2} \mathrm{O}, 0.0005 \mathrm{~g} ; \mathrm{CoCl}_{2} \cdot 6 \mathrm{H}_{2} \mathrm{O}, 0.0005 \mathrm{~g} ; \mathrm{NiCl}_{2}$. - $6 \mathrm{H}_{2} \mathrm{O}, 0.001 \mathrm{~g} ; \mathrm{Na}_{2} \mathrm{SeO}_{4} \cdot 10 \mathrm{H}_{2} \mathrm{O}, 0.001 \mathrm{~g} ; \mathrm{FeSO}_{4} \cdot 7 \mathrm{H}_{2} \mathrm{O}$, $0.005 \mathrm{~g}$. The vitamin solution had the following composition (per liter): biotin, $0.002 \mathrm{~g}$; folic acid, $0.002 \mathrm{~g}$; pyridoxine- $\mathrm{HCl}, 0.01 \mathrm{~g}$; thiamine- $\mathrm{HCl}, 0.005 \mathrm{~g}$; riboflavin, $0.005 \mathrm{~g}$; nicotinic acid, $0.005 \mathrm{~g}$; p-aminobenzoic acid, $0.005 \mathrm{~g}$; vitamin B12, $0.001 \mathrm{~g}$. Acetate $(5 \mathrm{mM})$ was used as the carbon source. The $\mathrm{pH}$ of the medium was adjusted to 7.0 using $\mathrm{HCl}$. From the stock medium solution, $9 \mathrm{ml}$ were dispensed into $22 \mathrm{ml}$ anaerobic vials and 2,3DCP or 2,4,6TCP were added as the main terminal electron acceptor after autoclaving to a final concentration of $50 \mu \mathrm{M}$. Vials were capped with Tefloncoated butyl rubber stoppers and sealed with aluminum 
caps. The head space was flushed with hydrogen gas. To remove dissolved oxygen and ensure anaerobic conditions, the medium was reduced with $\mathrm{Ti}$ (III)-citrate, with resazurin added as an indicator. Active cultures were maintained by transferring $1 \mathrm{ml}$ into $9 \mathrm{ml}$ of freshly prepared medium. Enrichment sediment-free cultures were obtained after at least five successive transfers of active cultures (10\%) into new medium containing CPs as electron acceptors. All cultures were incubated inverted at $30^{\circ} \mathrm{C}$ in the dark without shaking and were monitored for dechlorination activity by gas chromatographic analysis. Cultures showing dechlorination were diluted in the same medium and reincubated under the same conditions until sediment-free cultures were obtained.

Tested electron donors and acceptors. Different electron donors including, hydrogen, formate, lactate, pyruvate, and acetate at $5-\mathrm{mM}$ concentrations were tested. Chlorinated phenols, formate, lactate, pyruvate, acetate, and thiosulfate were tested as electron acceptors. When being used as a main electron acceptor, CPs were added to cultures at a final concentration of $50 \mu \mathrm{M}$.

Chemicals. Chlorinated phenol standards were obtained from Sigma-Aldrich (Deisenhofen, Germany) and were used as authentic samples to characterize unknown compounds.

Chemical analyses. Chlorinated phenols were analyzed after extraction from culture medium with methylene chloride using a gas chromatograph (GC-396B, GL Science, Japan) equipped with an Aquatic column $(60 \mathrm{~m} \times 0.32 \mathrm{~mm}$ I.D., $1.0 \mu \mathrm{m}$ df; GL Science) with an online Tekmar Dohrman headspace autosampler. A GC-4000 gas chromatograph (GL Science) equipped with a J\&W Scientific column $(30 \mathrm{~m} \times 0.53 \mathrm{~mm}$ I.D., $1.0 \mu \mathrm{m} \mathrm{df}$ ) was also used for direct sample injection and analysis. The following program was used to achieve maximum separation between peaks: column oven temperature, $40^{\circ} \mathrm{C}$ for $3 \mathrm{~min}, 40^{\circ} \mathrm{C}$ to $80^{\circ} \mathrm{C}$ at a rate of $8^{\circ} \mathrm{C} / \mathrm{min}, 80^{\circ} \mathrm{C}$ to $190^{\circ} \mathrm{C}$ at $44^{\circ} \mathrm{C} / \mathrm{min}, 190^{\circ} \mathrm{C}$ for $5 \mathrm{~min}$. Helium was used as the carrier gas. Chlorophenols concentrations were represented as means of three measurements from three independent experiments $( \pm S D)$.

DNA extraction and PCR amplification. Total community DNA was extracted using an Ultra Clean Soil DNA purification kit (Mo Bio Laboratories, Solana Beach, CA, USA). About $0.5 \mathrm{~g}$ from established microcosms or harvested cells from enrichment cultures were transferred to bead beating tubes and vortexed horizontally for $2 \mathrm{~min}$ at room temperature. DNA was precipitated and purified according to the instruction manual. Amplification of the 16S rRNA genes for DGGE analysis was performed using GC-clamp primers (EUB341F-GC: 5'-CGCCCGCCGCGCGCGGCGGGCGGGGCGGGGGCACGGGGGGCCTA CGGGAGGCAGCAGCAG-3' and EUB517R: 5'-ATTA CCGCGGCTGCTGG-3') (Muyzer et al., 1993). Ampli- fication was performed in a $25 \mu \mathrm{l}$ reaction containing: $2.5 \mu \mathrm{l}$ of $10 \times \mathrm{Taq}$ buffer (100 mM Tris-HCl, $\mathrm{pH} 8$ ), $1.25 \mathrm{mM} \mathrm{MgCl}_{2}, 100 \mu \mathrm{M}$ dNTPs (Invitrogen, Carlsbad, CA, USA), $1.2 \mu \mathrm{M}$ forward primer and reverse primer (Invitrogen), 0.5 U Taq DNA polymerase (Invitrogen), and about 5 ng of template DNA. PCR was performed in a Thermal Cycler (2720; Applied Biosystems, Foster City, CA, USA). A touchdown PCR program was implemented as follows: initial denaturation step at $95^{\circ} \mathrm{C}$ for $5 \mathrm{~min} ; 5$ cycles of $94^{\circ} \mathrm{C}$ for $40 \mathrm{~s}$, annealing at $65^{\circ} \mathrm{C}$ for $40 \mathrm{~s}$, and extension at $72^{\circ} \mathrm{C}$ for $40 \mathrm{~s} ; 5$ cycles of $94^{\circ} \mathrm{C}$ for $40 \mathrm{~s}$, annealing at $60^{\circ} \mathrm{C}$ for $40 \mathrm{~s}$, and extension at $72^{\circ} \mathrm{C}$ for $40 \mathrm{~s} ; 10$ cycles of $94^{\circ} \mathrm{C}$ for $40 \mathrm{~s}$, annealing at $55^{\circ} \mathrm{C}$ for $40 \mathrm{~s}$, and extension at $72^{\circ} \mathrm{C}$ for $40 \mathrm{~s}$; 10 cycles of $94^{\circ} \mathrm{C}$ for $40 \mathrm{~s}$, annealing at $50^{\circ} \mathrm{C}$ for $40 \mathrm{~s}$, and extension at $72^{\circ} \mathrm{C}$ for $40 \mathrm{~s}$ were performed, followed by a final hold at $72^{\circ} \mathrm{C}$ for $7 \mathrm{~min}$. Amplicons were analyzed by electrophoresis on $1 \%$ agarose gels with size markers (1 kb DNA ladder, Invitrogen) and visualized using ethidium bromide. Amplification of the cprA genes was performed with a combination of forward (dehaloF4: $5^{\prime}-(\mathrm{C} / \mathrm{T})(\mathrm{C} / \mathrm{A}) \mathrm{T}(\mathrm{G} / \mathrm{T}) \mathrm{GGTTA}(\mathrm{C} / \mathrm{T})(\mathrm{A} / \mathrm{T})$ ATGC-3') and reverse (dehaloR2: $5^{\prime}-\mathrm{T}(\mathrm{C} / \mathrm{T}) \mathrm{TGTAC}-$ CATAGCC-3') primers, which were designed from the conserved region in the cprA gene of $D$. dehalogenans (von Wintzingerode et al., 2001). The amplification protocol included an initial denaturation step at $95^{\circ} \mathrm{C}$ for $5 \mathrm{~min}, 30$ cycles of $94^{\circ} \mathrm{C}$ for $1 \mathrm{~min}$, annealing at $50^{\circ} \mathrm{C}$ for $2 \mathrm{~min}$, and extension at $72^{\circ} \mathrm{C}$ for $2 \mathrm{~min}$, followed by a final elongation step at $72^{\circ} \mathrm{C}$ for $7 \mathrm{~min}$. The amplified fragment was cloned into the pGEM-T Easy vector for sequencing.

DGGE. DGGE was performed using the Dcode Mutation Detection System (Bio-Rad Laboratories Ltd., Hertfordshire, UK). PCR products were electrophoresed on $8 \%$ polyacrylamide gels containing a $25 \%$ to $50 \%$ denaturing gradient of formamide and urea. Electrophoresis was performed in $0.5 \times \mathrm{TAE}$ buffer $(1 \times$ TAE buffer contains $0.04 \mathrm{M}$ Tris base, $0.02 \mathrm{M}$ sodium acetate, and $10 \mathrm{mM}$ EDTA, $\mathrm{pH} 7.4)$ at $60^{\circ} \mathrm{C}$ for $5 \mathrm{~h}$ at $200 \mathrm{~V}$. Gels were stained with SYBR Green I nucleic acid gel stain (Cambrex Bio Science, Rockland, MA, USA) and analyzed for DGGE band profiles with a UV Gel Doc XR documentation system (Bio-Rad Laboratories Inc., Hercules, CA, USA). Selected DGGE bands were excised and eluted by incubation in $100 \mu \mathrm{l}$ of TE buffer at $100^{\circ} \mathrm{C}$ for $5 \mathrm{~min}$. The supernatant was used as a template for reamplification of the $16 \mathrm{~S}$ rRNA genes using bacterial primers EUB314F, without the GC clamp, and EUB517R, prior to sequencing.

Cloning and sequencing. PCR products were ligated to the pGEM-T Easy vector (Promega, Madison, WI, USA) and used to transform Escherichia coli JM109 (Takara, Tokyo, Japan) according to the manufacturer's recommendations. Recombinant E. coli clones were 
screened for correct inserts by colony PCR. Recombinant plasmid DNA of positive clones was extracted using the Wizard Plus SV Miniprep DNA purification system (Promega) and used for sequencing. BigDye terminator cycle sequencing (Sanger et al., 1977) was performed with an ABI 310 genetic analyzer (Applied Biosystems) using dye terminator-based PCR products amplified with the vector-specific forward primer M13F according to the instruction manual.

Sequence and phylogenetic analysis. Obtained sequences were processed for analysis using the Genetyx-Win MFC application software version 4.0. Sequences were identified and compared with their nearest phylogenetic neighbors using the BLAST search program, National Center for Biotechnology Information (NCBI), National Library of Medicine, USA (www.ncbi.nlm.nih.gov/BLAST/) (Altschul et al., 1997). Sequence alignments were performed using Clustal W1.83 XP software (Thompson et al., 1997) and phylogenetic trees were constructed using the neighborjoining method (Saitou and Nei, 1987) and MEGA6 software (Kumar et al., 2004).

Nucleotide sequence accession numbers. Sequences of the $16 \mathrm{~S}$ rDNA gene identified in this study have been deposited in the GenBank database under the accession numbers (LC010626-LC010637). The cprA gene sequences have been deposited under the accession numbers (LC010638-LC010645).

\section{Results}

Dechlorination in established anaerobic cultures. Microcosms and enrichment cultures maintained under optimum conditions of temperature and $\mathrm{pH}$ showed a dechlorination activity against CPs. Figure 1 shows the detection of $2 \mathrm{CP}$ and $3 \mathrm{CP}$ as dechlorination products from microcosms amended with 2,3DCP. In enrichment cultures, complete dechlorination of $50 \mu \mathrm{M} 2,3 \mathrm{DCP}$ to $3 \mathrm{CP}$ and 2,4,6TCP to 2,4DCP, 4CP within 3 weeks of incubation was observed (Fig. 2). Dechlorination activity was favored with ortho chlorine, however, detection of trace amounts of 2CP in 2,3DCP-dechlorinating cultures revealed the weak dechlorination activity of meta chlorine. Dechlorination was found to be mainly site specific. 2,4,6TCP exhibited dechlorination of orthochlorine producing mainly 2,4DCP. Dechlorination beyond 2,4DCP yield 4CP mainly with trace amounts of $2 \mathrm{CP}$. Figure 3 shows the proposed reductive dechlorination routes for both 2,3DCP and 2,4,6TCP in established cultures. Dechlorination and growth were found to be dependent on the presence of acetate as a carbon source in the culture medium. Hydrogen was found to be necessary as an electron donor for efficient dechlorination of 2,3DCP and 2,4,6TCP. Among different

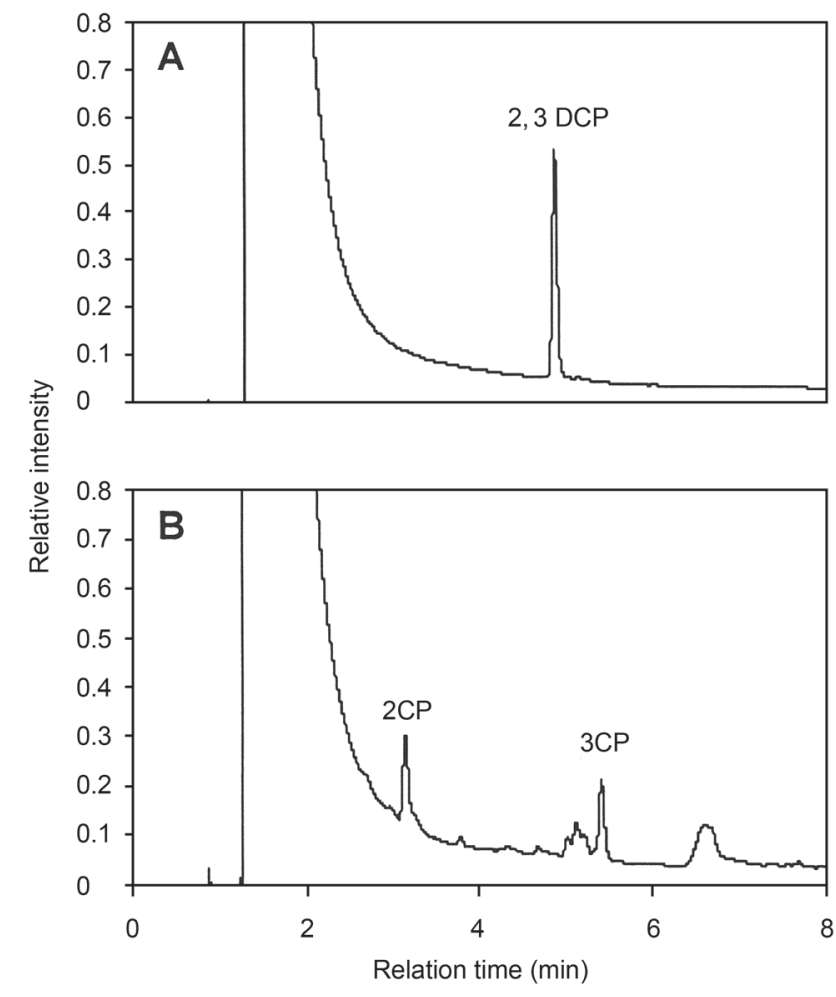

Fig. 1. Detection of dechlorination activity in established microcosms.

(A) GC chromatogram showing 2,3DCP as a starting compound spiked to microcosms. (B) GC chromatogram showing transformation of $2,3 \mathrm{DCP}$ to $2 \mathrm{CP}$ and $3 \mathrm{CP}$ after prolonged time of incubation as a result of dechlorination activity.

organic acids tested, only lactate can replace hydrogen as an electron donor. However, the rate of dechlorination was decreased and cultures lost dechlorination activity after successive transfers.

Bacterial community structure in dechlorinating cultures. The DGGE fingerprints obtained in this study with metagenomic DNA from microcosms amended with 2,3DCP and 2,4,6TCP showed changes in the bacterial community structure from the original sediment. Community fingerprints of microcosms supplemented with either 2,3DCP or 2,4,6TCP were stable and showed no significant changes in the DGGE profiles even after a prolonged incubation time. The DGGE profiles for 2,3DCP or 2,4,6TCP dechlorinating microcosms showed the predominance of eight major Operational Taxonomic Units (OTUs) (Fig. 4A). Sequencing of the dominant DGGE bands of 16S rRNA gene assigned these OTUs to members of the genera Citrobacter, Geobacter, Pseudomonas, Desulfitobacterium, Desulfovibrio, and Clostridium (Table I). Different DGGE profiles were observed when enrichment cultures were compared with dechlorinating microcosms. Enrichment resulted in loss of at least four of the microcosm bacterial members, represented by bands A1 (Citrobacter sp.), A2 (Geobacter sp.), A6 (Desulfovibrio sp.), and A7 (Clostridium sp.). Highly enriched dechlorinating 

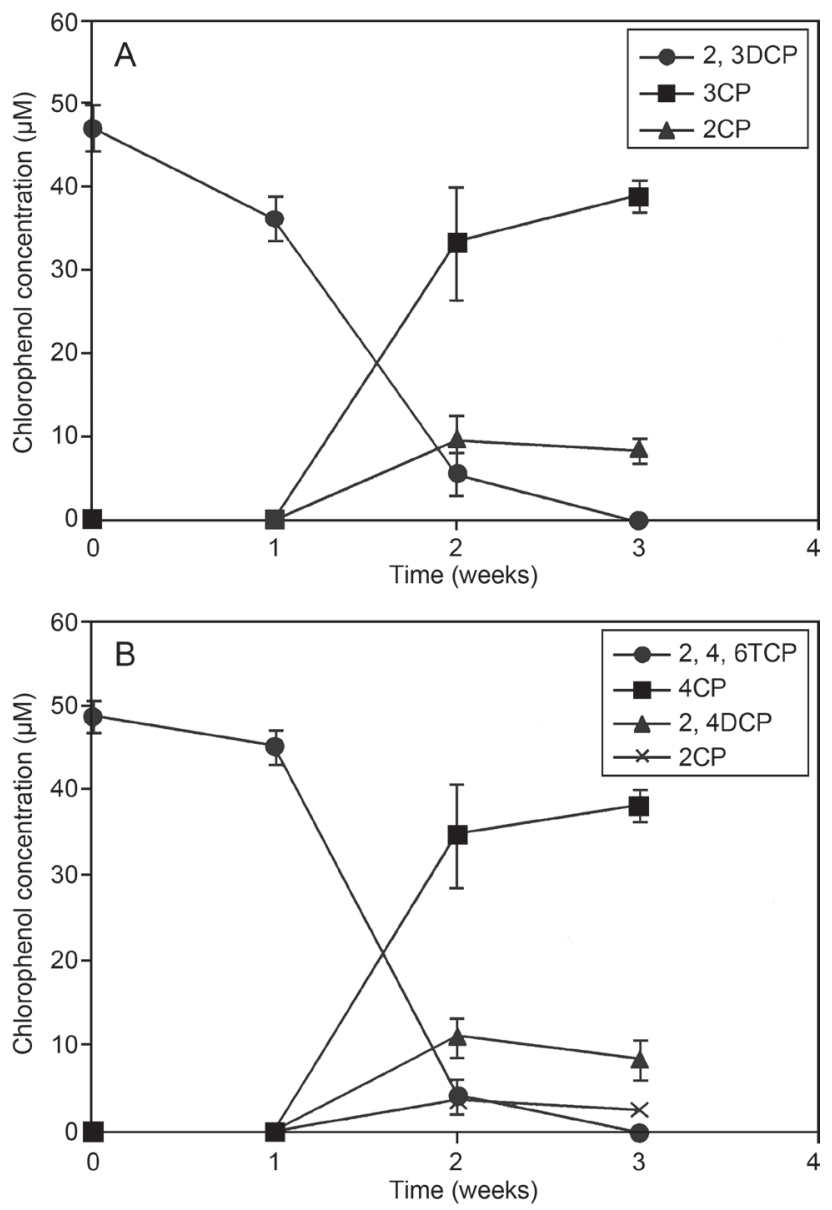

Fig. 2. Changes in chlorophenol concentration in enrichment cultures over time.

(A) Dechlorination of 2,3DCP to $3 \mathrm{CP}$ and $2 \mathrm{CP}$. (B) Dechlorination of 2,4,6TCP to 2,4DCP with further dechlorination to 4CP and 2CP. Each bar represents the mean and standard deviation of three replicates samples.

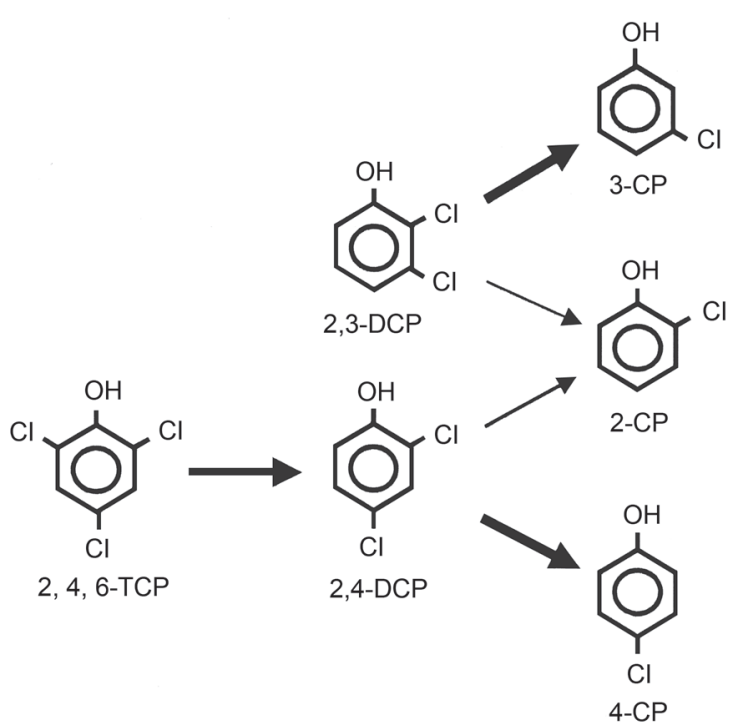

Fig. 3. Proposed pathway for 2,3DCP and 2,4,6TCP dechlorination in highly enriched cultures.

Dechlorination was favored at ortho position. Low dechlorination activity was observed at meta position of 2,3DCP, or para position of 2,4,6TCP. TCP was dechlorinated at ortho position successively giving 2,4-DCP and finally 4-CP. Small amount of 2-CP was detected.

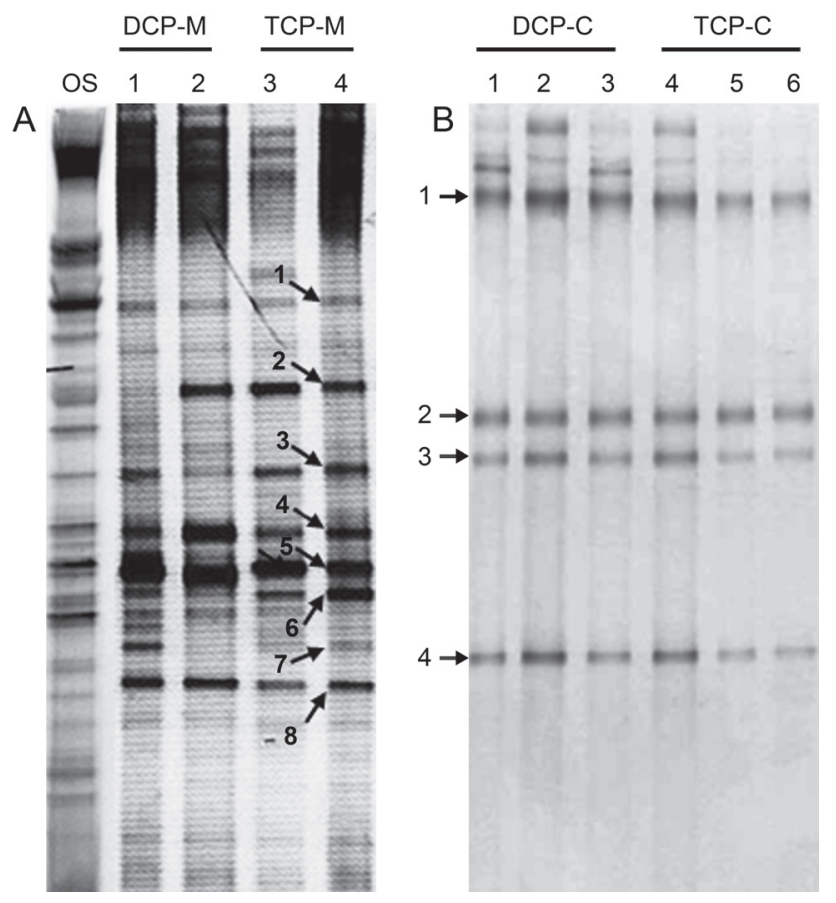

Fig. 4. DGGE fingerprints of $16 \mathrm{~S}$ rRNA gene fragments from established dechlorinating microcosms (A) and enrichment cultures (B).

Lane OS represents bacterial fingerprint of original sediment. Lane 1,2 represent fingerprints obtained from genomic DNA of DCP dechlorinating microcosms while lane 3,4 represent those from TCP dechlorinating microcosms. Lane 1,2,3 corresponds to bacterial populations of highly enriched DCP dechlorination cultures, while lane 4,5,6 correspond to those of TCP dechlorination cultures.

cultures comprised four major OTUs (Fig. 4B), which were identified as members of the genera Pseudomonas, Desulfitobacterium and uncultured Clostridium.

Identification of dechlorinating bacteria. This study also investigated the microorganisms responsible for dechlorination in sediment microcosms or enrichment cultures. The DGGE microcosm OTU A4 is similar to OTU B2, which was detected in enriched dechlorinating cultures. Both OTUs have been assigned to the genus Desulfitobacterium, which is known for its ability to couple dechlorination to growth via halorespiration. The DGGE pattern of cultures lacking dechlorination activity revealed the absence of OTU B2, indicating its direct involvement in dechlorination. Direct microscopic examination of highly enriched dechlorinating cultures showed the predominance of curved rod-shaped bacteria, a characteristic morphology of Desulfitobacterium. Taken together, these results provide compelling evidence that both OTUs A4 and B2 identified as Desulfitobacterium sp. were responsible for dechlorination of 2,3DCP and 2,4,6TCP, lowing the concentration of CPs.

Detection of the chlorophenol RD gene (cprA). To detect the chlorophenol RD encoding gene (cprA gene) from microcosms and dechlorinating cultures, PCR amplification using the primer set dehaloF4/ 
Table I

OTUs identified in established microcosms and enrichment cultures with their phylogenetic affiliations.

\begin{tabular}{|c|c|c|c|c|c|}
\hline \multirow[b]{2}{*}{$\begin{array}{l}\text { DGGE } \\
\text { bands }\end{array}$} & \multirow[b]{2}{*}{$\begin{array}{l}\text { Accession } \\
\text { No. }\end{array}$} & \multicolumn{3}{|l|}{ Closest match } & \multirow[b]{2}{*}{ Phylogenetic affiliation } \\
\hline & & Identity & \begin{tabular}{|c|} 
Accession \\
No.
\end{tabular} & $\begin{array}{c}\text { Similarity } \\
(\%)\end{array}$ & \\
\hline \multirow[t]{5}{*}{$\mathrm{A} 1$} & \multirow[t]{5}{*}{ LC010626 } & Citrobacter freundii MW-D 2220 & KC835086 & 98 & Gammaproteobacteria \\
\hline & & Citrobacter sp. F3-7 & EF491835 & 98 & Gammaproteobacteria \\
\hline & & Enterobacter sp. 18A & HQ289882 & 98 & Gammaproteobacteria \\
\hline & & Klebsiella sp. SUS9K & KF991505 & 98 & Gammaproteobacteria \\
\hline & & $\begin{array}{l}\text { Uncultured Enterobacteriaceae bacterium } \\
\text { C146500177 }\end{array}$ & JX531197 & 98 & Gammaproteobacteria/Environmental sample \\
\hline \multirow[t]{5}{*}{$\mathrm{A} 2$} & \multirow[t]{5}{*}{ LC010627 } & Geobacter lovleyi Geo7.1A & JN982204 & 99 & Deltaproteobacteria \\
\hline & & Geobacter thiogenes $\mathrm{K} 1$ & NR028775 & 99 & Deltaproteobacteria \\
\hline & & $\begin{array}{l}\text { Uncultured Geobacter sp. clone } \\
\text { MFC-1-L16 }\end{array}$ & JX944529 & 99 & Deltaproteobacteria/Environmental sample \\
\hline & & $\begin{array}{l}\text { Uncultured delta proteobacterium } \\
\text { clone CF_05 }\end{array}$ & EF562566 & 99 & Deltaproteobacteria/Environmental sample \\
\hline & & $\begin{array}{l}\text { Geobacter sp. enrichment culture clone } \\
\text { MC18B6-5 }\end{array}$ & JQ256498 & 99 & Deltaproteobacteria/Environmental sample \\
\hline \multirow[t]{5}{*}{$\mathrm{A} 3$} & \multirow[t]{5}{*}{ LC010628 } & Pseudomonas fulva Z47 & KF835747 & 100 & Gammaproteobacteria \\
\hline & & Pseudomonas putida $\mathrm{P} 1$ & KJ960183 & 99 & Gammaproteobacteria \\
\hline & & Pseudomonas aeruginosa P17 & KJ960182 & 99 & Gammaproteobacteria \\
\hline & & Pseudomonas stutzeri 54DMH1 & KM025368 & 99 & Gammaproteobacteria \\
\hline & & Pseudomonas sp. IMARCUG-3 & KJ918745 & 99 & Gammaproteobacteria \\
\hline \multirow[t]{5}{*}{ A4 } & \multirow[t]{5}{*}{ LC010629 } & Desulfitobacterium sp. CR1 & AB299028 & 100 & Clostridia \\
\hline & & Desulfitobacterium sp. RPf35Ei & AY548779 & 97 & Clostridia \\
\hline & & $\begin{array}{l}\text { Desulfitobacterium dichloroeliminans } \\
\text { LMG P-21439 }\end{array}$ & NR102483 & 96 & Clostridia \\
\hline & & Desulfitobacterium hafniense DCB-2 & NR121797 & 95 & Clostridia \\
\hline & & $\begin{array}{l}\text { Desulfitobacterium dehalogenans } \\
\text { JW/IU-DC1 }\end{array}$ & NR044641 & 95 & Clostridia \\
\hline \multirow[t]{5}{*}{ A5 } & \multirow[t]{5}{*}{ LC010630 } & Pseudomonas putida strain P1 & KJ960183 & 99 & Gammaproteobacteria \\
\hline & & Pseudomonas aeruginosa P17 & KJ960182 & 99 & Gammaproteobacteria \\
\hline & & Pseudomonas stutzeri 54DMH1 & KM025368 & 99 & Gammaproteobacteria \\
\hline & & Pseudomonas sp. IMARCUG-3 & KJ918745 & 99 & Gammaproteobacteria \\
\hline & & Pseudomonas sp. JS-C55 & KJ921736 & 99 & Gammaproteobacteria \\
\hline \multirow[t]{5}{*}{ A6 } & \multirow[t]{5}{*}{ LC010631 } & Desulfovibrio vulgaris Miyazaki F & CP001197 & 100 & Deltaproteobacteria \\
\hline & & Desulfovibrio sp. wpp1 & KF601938 & 100 & Deltaproteobacteria \\
\hline & & Uncultured Desulfovibrio sp. clone immo-6 & AB936633 & 100 & Deltaproteobacteria/ Environmental sample \\
\hline & & Desulfovibrio sp. enrichment culture clone 2 & JF714419 & 100 & Deltaproteobacteria/ Environmental sample \\
\hline & & $\begin{array}{l}\text { Uncultured delta proteobacterium } \\
\text { clone SRB4 }\end{array}$ & DQ069228 & 100 & Deltaproteobacteria/ Environmental sample \\
\hline \multirow[t]{5}{*}{ A7 } & \multirow[t]{5}{*}{ LC010632 } & $\begin{array}{l}\text { Uncultured Clostridium sp. clone } \\
\text { BacBotHigh001 }\end{array}$ & JF731763 & 100 & Clostridia/Environmental sample \\
\hline & & Clostridium sp. M-43 & AB504378 & 99 & Clostridia \\
\hline & & Uncultured bacterium clone PSM25 & AB639316 & 99 & Environmental sample \\
\hline & & Clostridium sp. S11-3-10 & AB838978 & 98 & Clostridia \\
\hline & & Uncultured Clostridium sp. clone XT41 & KF511913 & 97 & Clostridia/Environmental sample \\
\hline \multirow[t]{3}{*}{ A8 } & \multirow[t]{3}{*}{ LC010633 } & Uncultured Clostridium sp. DGGE-GZ-C7 & KC529382 & 100 & Clostridia/Environmental sample \\
\hline & & Uncultured Clostridium sp. clone A05 & JX545163 & 100 & Clostridia/Environmental sample \\
\hline & & $\begin{array}{l}\text { Clostridium sp. enrichment culture } \\
\text { DGGE-gz-5d-15 }\end{array}$ & JX470312 & 100 & Clostridia/Environmental sample \\
\hline
\end{tabular}


Fig. 5. Detection of chlorophenol reductive dehalogenase encoding gene, cprA in Nile river sediment microcosms and established enrichment cultures.

(A) Schematic representation of the cpr gene locus in D. dehalogenans (Smidt et al., 2000) showing target cprA gene and the sequenced region in this study covering up the Fe-S cluster. (B) PCR amplification of Fe-S cluster region of cprA clones from DCP and TCP cultures as well as dechlorinating microcosms. Lane $\mathrm{M}$ represents the size marker $(1 \mathrm{~Kb}$ DNA ladder, Invitrogen, USA).

dehaloR2 was performed with an expected product size of approximately $600 \mathrm{bp}$ (Fig. 5B). Eight clones were recovered from DCP and TCP dechlorinating cultures. Sequence analysis of the obtained clones from DCP and TCP dechlorinating cultures showed sequence
A

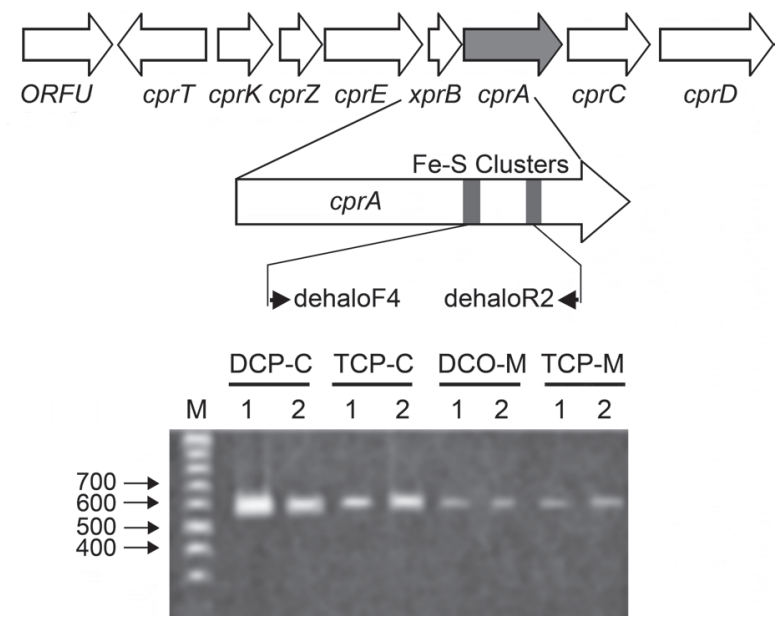

similarity of $99 \%$ to the cprA gene from uncultured bacterium DCB and $96-98 \%$ to the cprA gene from Dehalobacter restrictus.

Phylogenetic analysis of the cprA genes. When aligned to available sequences in the public databases,

Table I continued

\begin{tabular}{|c|c|c|c|c|c|}
\hline \multirow[b]{2}{*}{$\begin{array}{l}\text { DGGE } \\
\text { bands }\end{array}$} & \multirow[b]{2}{*}{$\begin{array}{l}\text { Accession } \\
\text { No. }\end{array}$} & \multicolumn{3}{|l|}{ Closest match } & \multirow[b]{2}{*}{ Phylogenetic affiliation } \\
\hline & & Identity & $\begin{array}{l}\text { Accession } \\
\text { No. }\end{array}$ & \begin{tabular}{|c|} 
Similarity \\
$(\%)$
\end{tabular} & \\
\hline \multirow[t]{2}{*}{ A8 } & \multirow[t]{2}{*}{ LC010633 } & $\begin{array}{l}\text { Clostridium sp. enrichment culture } \\
\text { clone N6 }\end{array}$ & JQ420069 & 100 & Clostridia/Environmental sample \\
\hline & & Uncultured bacterium clone LBAC143 & KJ601180 & 100 & Environmental sample \\
\hline \multirow[t]{5}{*}{ B1 } & \multirow[t]{5}{*}{ LC010634 } & Pseudomonas stutzeri $\mathrm{YC}-\mathrm{YH} 1$ & KJ786450 & 99 & Gammaproteobacteria \\
\hline & & Pseudomonas pseudoalcaligenes & LK391695 & 99 & Gammaproteobacteria \\
\hline & & Pseudomonas sp. NEAU-ST5-5 & JQ762269 & 99 & Gammaproteobacteria \\
\hline & & Uncultured Pseudomonas sp. clone 1-22-20 & KJ650703 & 99 & Gammaproteobacteria/Environmental sample \\
\hline & & $\begin{array}{l}\text { Uncultured Pseudomonadaceae bacterium } \\
\text { c:S2-8094 }\end{array}$ & KF786991 & 99 & Gammaproteobacteria/Environmental sample \\
\hline \multirow[t]{5}{*}{ B2 } & \multirow[t]{5}{*}{ LC010635 } & Desulfitobacterium sp. CR1 & AB299028 & 100 & Clostridia \\
\hline & & Desulfitobacterium sp. RPf35Ei & AY548779 & 97 & Clostridia \\
\hline & & $\begin{array}{l}\text { Desulfitobacterium dichloroeliminans } \\
\text { LMG P- } 21439\end{array}$ & NR102483 & 96 & Clostridia \\
\hline & & Desulfitobacterium hafniense DCB-2 & NR121797 & 95 & Clostridia \\
\hline & & $\begin{array}{l}\text { Desulfitobacterium dehalogenans } \\
\text { JW/IU-DC1 }\end{array}$ & NR044641 & 95 & Clostridia \\
\hline \multirow[t]{5}{*}{ B3 } & \multirow[t]{5}{*}{ LC010636 } & Pseudomonas putida strain P1 & KJ960183 & 99 & Gammaproteobacteria \\
\hline & & Pseudomonas aeruginosa P17 & KJ960182 & 99 & Gammaproteobacteria \\
\hline & & Pseudomonas stutzeri 54DMH1 & KM025368 & 99 & Gammaproteobacteria \\
\hline & & Pseudomonas sp. IMARCUG-3 & KJ918745 & 99 & Gammaproteobacteria \\
\hline & & Pseudomonas sp. JS-C55 & KJ921736 & 99 & Gammaproteobacteria \\
\hline \multirow[t]{5}{*}{ B4 } & \multirow[t]{5}{*}{ LC010637 } & Uncultured Clostridium sp. DGGE-GZ-C7 & KC529382 & 100 & Clostridia/Environmental sample \\
\hline & & Uncultured Clostridium sp. clone A05 & JX545163 & 100 & Clostridia/Environmental sample \\
\hline & & $\begin{array}{l}\text { Clostridium sp. enrichment culture } \\
\text { DGGE-gz-5d-15 }\end{array}$ & JX470312 & 100 & Clostridia/Environmental sample \\
\hline & & $\begin{array}{l}\text { Clostridium sp. enrichment culture } \\
\text { clone N6 }\end{array}$ & JQ420069 & 100 & Clostridia/Environmental sample \\
\hline & & Uncultured bacterium clone LBAC143 & KJ601180 & 100 & Environmental sample \\
\hline
\end{tabular}




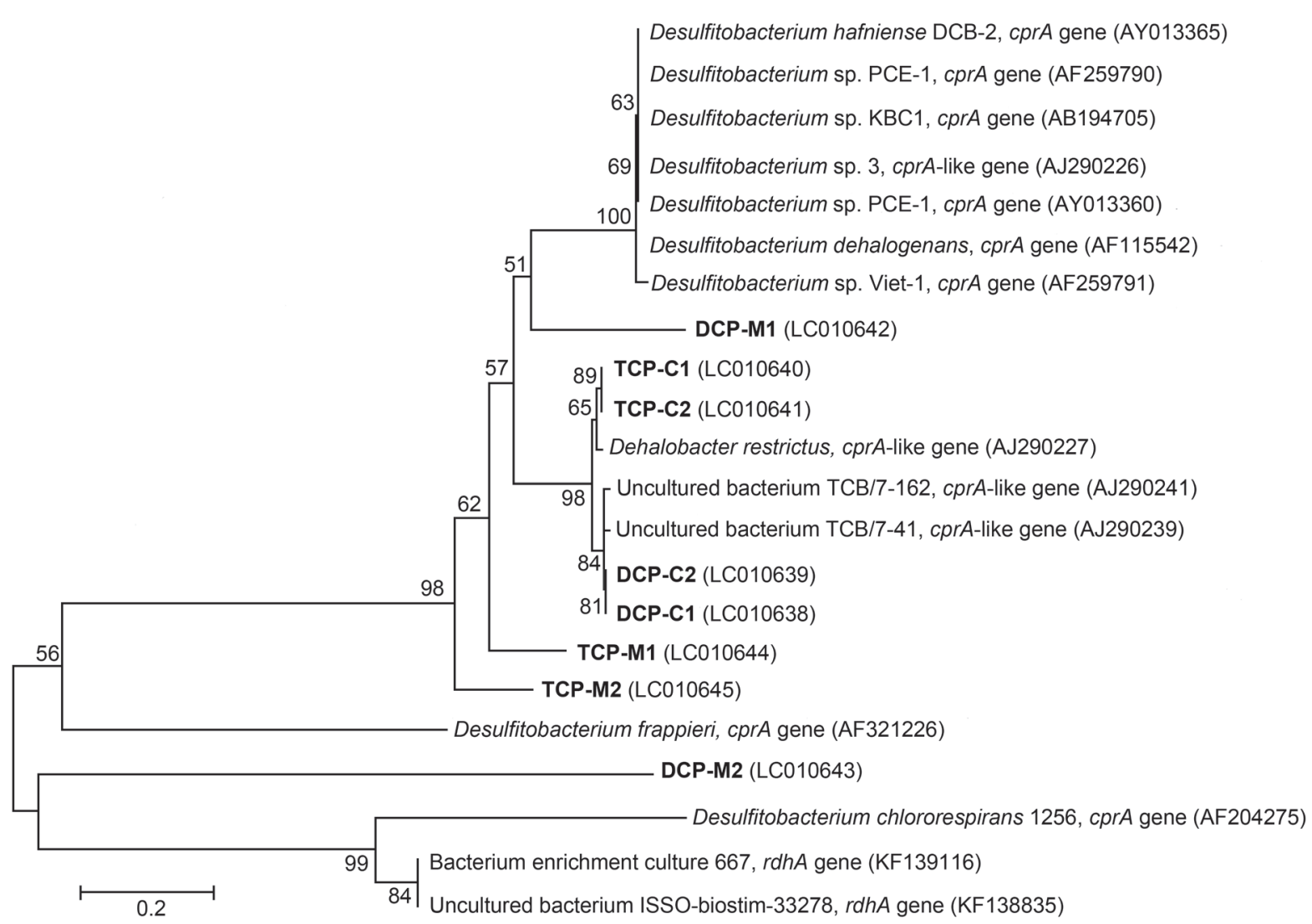

Fig. 6. Neighbour-joining tree showing the phylogenetic distribution of cprA gene fragments from microcosms and enrichment cultures. The dendrogram was constructed from a ClustalW alignment and Mega 3 analysis. Nodes supported by bootstrap values greater than 50 are indicated. Accession numbers of clones (boldface) and reference sequences from GenBank are indicated in parentheses. The scale bar represents substitutions per nucleotide.

the cprA genes cloned from microcosms was closely related to the cprA gene from uncultured bacterium TCB (97\%), D. restrictus (96\%), Desulfitobacterium frappieri (82\%), D. hafniense (82\%), and D.chlororespirans $(84 \%)$. The cprA genes cloned from enriched cultures were closely related to those from uncultured bacterium DCP (99\%), D. restrictus (98\%), D. chlororespirans (85\%), D. hafniense (82\%), and D. frappieri (86\%). Figure 6 shows the phylogenetic relationships between the detected cprA clones and those from reported dechlorinating bacteria.

\section{Discussion}

Organohalide respiration is a unique metabolic process that is implicated in the global halogen cycle and is of environmental significance for remediation purposes. As part of anaerobic dehalogenation processes, reductive dechlorination has triggered considerable interest for the potential detoxification of anthropogenic groundwater contaminants (Hug and Edwards, 2013). Anaerobic reductive dechlorination has been studied in a number of sedimentary environments (Lake et al., 1992; Alder etal., 1993; Wu et al.,
1998; Fagervold et al., 2005; Fung et al., 2009; Itoh et al., 2010). These investigations were made possible using laboratory microcosms. Anaerobic reductive dechlorination of chlorinated benzenes for example was investigated in microcosms containing chloroaromatic-contaminated river sediment (Vandermeeren et al., 2014). Dechlorination activity in enrichment cultures showed at least three different dechlorination reactions. A distinct ortho-dechlorinating path for 2,3DCP, 2,4DCP, and 2,4,6TCP was predominant. However, meta- and para-dechlorination paths also existed with slow rates and restriction to 2,3DCP and 2,4DCP, respectively. Although some strains were reported to exhibit chlorophenols dechlorination of all three substituent (ortho, meta, and para) positions (Thibodeau etal., 2004; Gauthier et al., 2006), this pattern of dechlorination was restricted to the ortho position, consistent with dechlorination reported for the anaerobic bacterium, strain PCE1 (Gerritse et al., 1996). In enrichment cultures, dechlorination beyond monochlorophenols was not detected. This pattern of dechlorination is most similar to that reported for D. chlororespirans, which was able to dechlorinate ortho chlorines of polysubstituted phenols to monohalophenol end products (Sanford et al., 1996). However, the chlorophenol concentration may 
represent a limiting factor for dechlorination activity as a higher concentration of CPs may result in reduction of dechlorination activity due to the cytotoxicity of these compounds. It has been reported that bacteria may develop some traits to overcome the cytotoxicity of higher CP concentrations. Surfactant production was found to have a role in overcoming the toxicity of chlorophenols (Chrzanowski et al., 2009). Rhamnolipids, in particular, were found to reduce the toxicity of CPs due to their accumulation in biosurfactant micelles and hydrophobic interactions with rhamnolipid-based dissolved organic carbon (Chrzanowski et al., 2011).

Dechlorination activity could only be serially transferred in enrichments containing hydrogen as an added electron donor. Dechlorinating cultures have a strict requirement for hydrogen. A variety of alternative electron donors have been reported to support reductive dechlorination (Gerritse et al., 1999), however, in this study, electron donors other than hydrogen failed to support dechlorination. Lactate has been found to be used by a number of dehalorespiring bacteria as an electron donor (Li et al., 2013). D. chlororespirans strain Co23 was able to grow by coupling the oxidation of lactate to the reductive dechlorination of 3-chloro4-hydroxybenzoate and 2,3-DCP (Sanford et al., 1996). However, it was found in this study that cultures growing with lactate were not stable and lost dechlorination activity after successive transfers. Different organic acids are used as the electron donors by some bacterial species; however, hydrogen is thought to be the most important electron donor for dehalorespiration, because of the high affinity of dehalorespiring bacteria for hydrogen (Luijten et al., 2004). Competition for hydrogen is known to exist among hydrogen-utilizing microorganisms in anoxic environments. In such habitats, where the hydrogen concentration is limited, the threshold ecosystem hydrogen concentration is controlled by microbial populations that couple hydrogen oxidation to thermodynamically favorable electron accepting reactions, including reductive dehalogenation (Mazur and Jones, 2001; Mazur et al., 2003). The establishment of sediment-free highly enriched reductive dechlorinating cultures would require hydrogen amendment to replace that provided by co-cultured bacteria. The presence of acetate was found to be important for sustaining stable dechlorinating cultures. It is suggested that acetate may play an important role as a carbon source to support the growth of dechlorinating bacteria and other associated bacteria. This differs from the reported role of acetate as an electron donor for growth coupled to reductive dechlorination (Sun et al., 2000).

The diversity of organohalide-respiring bacteria has not yet been fully described. Ongoing research in this field may lead to the discovery of novel strains, species and even new genera that could be implemented in bioremediation processes (Hug et al., 2013). The metagenomes of microbial communities are currently under investigation to reveal the metabolic interactions within organohalide-respiring consortia. Some consortia have been developed and characterized for organohalide-respiring populations and associated bacteria (Duhamel and Edwards, 2007; Rowe et al., 2008; Brisson et al., 2012; Hug, 2012; Maphosa et al., 2012). PCR-DGGE analysis using 16S rRNA genes usually yields patterns that reflect the composition of dominant microorganisms, including the nonculturable members (Gelsomino et al., 1999). The DGGE patterns obtained in this study with total community DNA showed changes in the dominant bacterial populations of native river sediment compared with CP amended microcosms. However, the bacterial community structure of 2,3DCP and 2,4,6TCP dechlorinating microcosms were similar and have remained largely intact over time. The DGGE profile for 2,3DCP or 2,4,6TCP dechlorinating microcosms revealed the predominance of eight major OTUs identified as members of the genera Citrobacter, Geobacter, Pseudomonas, Desulfitobacterium, Desulfovibrio, and Clostridium. Based on these detected genera, dechlorination has been assigned to Desulfitobacteria due to its reported ability to dechlorinate a variety of aryl halides and couple dechlorination to growth for its respiration (Smidt et al., 2000; Löffler et al., 2003; Holliger et al., 1998). The presence of Desulfovibrio in dechlorinating microcosms suggests its possible indirect role in dechlorination via syntrophic association with existing dehalorespiring bacteria (Drzyzga et al., 2001). Geobacter, as well as being detected in established dechlorinating microcosms, has also been suggested to play a role in organohalide respiration (Wagner et al., 2012). Cultures devoid of the distinct DGGE band assigned to Desulfitobacterium, lack any dechlorination activity, providing clear evidence that Desulfitobacterium sp. play a key role in the dechlorination of 2,3DCP and 2,4,6TCP. Desulfitobacterium spp. have been cited in many studies as dechlorinating bacteria (Bouchard et al., 1996; Breitenstein et al., 2001; Cupples et al., 2005; Villemur et al., 2006). Highly enriched cultures showed the prevalence of curved rods, a characteristic feature of Desulfitobacterium spp. (Villemur et al., 2006). Although some physiological characteristics of Desulfitobacterium spp. were reported, they did not match the dechlorination requirements in established dechlorinating cultures, suggesting a novel type of Desulfitobacterium with alternative physiological requirements. The requirements for dechlorination in this study were found to be similar to those reported for Dehalobacter sp. strain TCP1 when dechlorinating 2,4,6-TCP to 4-CP with hydrogen as the sole electron donor and acetate as the carbon source (Wang et al., 2014). Further attempts to isolate dechlorinating 
bacteria were unsuccessful indicating the possible existence of syntrophic interactions, as co-culture consortia, within dechlorinating communities.

Reductive dehalogenase (RD) encoding genes ( $r d h \mathrm{~A})$ have been identified in a wide variety of strictly anaerobic aryl halide respiring bacteria (Löffler et al., 1996; Christiansen et al., 1998; van de Pas et al., 1999; Thomas et al., 2008). Hug and Edwards (2013) reported that the RD complement within an organism, enrichment culture, or contaminated site, is of critical importance for determining the potential dechlorination activity. In this study, cprA RD genes were detected in dechlorinating microcosms and enrichment cultures (Fig. 5A, $\mathrm{B})$, showing similarity to the cprTKZEBACDA operon of D. dehalogenans (Smidt et al., 2000). The cprA gene was not detected in cultures lacking dechlorination activities suggesting its key role in catalyzing orthochlorine removal from either 2,3 DCP or 2,4,6-TCP. Analysis of cprA gene clones retrieved from both DCP and TCP dechlorinating cultures revealed eight distinct sequences, some with high sequence similarity to $D$. restrictus and some with relatively low sequence similarly to Desulfitobacterium spp. DGGE profiling revealed only one OTU affiliated to Desulfitobacterium sp., suggesting the presence of different copies of the cprA gene. D. hafniense strain PCP-1 was reported to possess two RDs encoded by crdA and cprA5 (Villemur et al., 2002). These two RD genes have also been found in several other Desulfitobacterium strains (Gauthier et al., 2006). The fact that several RD encoding genes exist in Desulfitobacterium spp. suggests the presence of distinct but related enzymes to achieve the dehalogenation of several chlorinated compounds.

\section{Conclusion}

The current study demonstrated the potential for reductive dechlorination of CPs in the sediment from a contaminated site of the River Nile by naturally occurring bacteria. Highly enriched, stable dechlorinating cultures were established using acetate as the carbon source, hydrogen as the electron donor, and CPs as electron acceptors. Metagenomic analysis of a highly enriched chlorophenol-reductive dechlorinating consortium revealed the predominance of Pseudomonas, Desulfitobacterium, and two uncultured Clostridia. Dechlorination was mainly assigned to Desulfitobacterium, as its absence resulted in complete loss of dechlorination. Chlorophenol RD cprA gene fragments were retrieved from dechlorinating cultures. The cprA gene was only detected by amplification in active dechlorinating cultures confirming dehalorespiration of chlorophenols. Several copies of the cprA genes were detected with high similarity to the $\mathrm{RD}$ of $D$. restrictus. Phylo- genetic analysis based on cprA sequences indicated that dechlorinating cultures had a wide distribution of cprA types. Collectively, these results provide valuable insights into potential bioremediation applications especially in anaerobic environments.

\section{Acknowledgments}

This work was partially supported by grants from the New Energy and Industrial Technology Development Organization (NEDO) through Central Research Institute of Electric Power Industry, Biotechnology Sector, Abiko, Japan. We are grateful to the scientists and crew of Environmental Science Research Laboratory for technical assistance. We additionally thank Biology department, Taibah University for providing technical support for completion of this work.

\section{Literature}

Alder A., C.M.M. Häggblom, S.R. Oppenheimer and L.Y. Young. 1993. Reductive dechlorination of polychlorinated biphenyls in anaerobic sediments. Environ. Sci. Technol. 27: 530-538.

Altschul S.F., T.L. Madden, A.A. Schäffer, J. Zhang, Z. Zhang, W. Miller and D.J. Lipman. 1997. Gapped blast and psi-blast: a new generation of protein database search programs. Nucleic Acid Res. 25: 3389-3402.

Bouchard B., R. Beaudet, R. Villemur, G. McSween, F. Lepine and J.G. Bisaillon. 1996. Isolation and characterization of Desulfitobacterium frappieri sp. nov., an anaerobic bacterium which reductively dechlorinates pentachlorophenol to 3-chlorophenol. Int. J. Syst. Bacteriol. 46: 1010-1015.

Breitenstein A., A. Saano, M. Salkinoja-Salonen, J.R. Andreesen and U. Lechner. 2001. Analysis of a 2,4,6-trichlorophenol-dehalogenating enrichment culture and isolation of the dehalogenating member Desulfitobacterium frappieri strain TCP-A. Arch. Microbiol. 175: 133-142.

Brisson V.L., K.A. West, P.K.H. Lee, S.G. Tringe, E.L. Brodie and L. Alvarez-Cohen. 2012. Metagenomic analysis of a stable trichloroethene-degrading microbial community. ISME J. 6: 1702-1714. Christiansen N. and B.K. Ahring. 1996. Desulfitobacterium hafniense sp. nov., an anaerobic, reductively dechlorinating bacterium. Int. J. Syst. Bacteriol. 46: 442-448.

Christiansen N., B.K. Ahring, G. Wohlfarth and G. Diekert. 1998. Purification and characterization of the 3-chloro-4-hydroxy-phenylacetate reductive dehalogenase of Desulfitobacterium hafniense. FEBS Lett. 436: 159-162.

Chrzanowski L., L.Y. Wick, R. Meulenkamp, M. Kaestner and H.J. Heipieper. 2009. Rhamnolipid biosurfactants decrease the toxicity of chlorinated phenols to Pseudomonas putida DOT-T1E. Lett. App. Microbiol. 48: 756-762.

Chrzanowski L., M. Owsianiak, A. Szulc, R. Marecik, A.P. Cyplik, A.K.O Schmidt, J. Staniewski, P. Lisiecki, F. Ciesielczyk, T. Jesionowski and others. 2011. Interactions between rhamnolipid biosurfactants and toxic chlorinated phenols enhance biodegradation of a model hydrocarbon-rich effluent. International Biodeterioration and Biodegradation 65:605-611.

Cole J.R., A.L. Cascarelli, W.W. Mohn and J.M. Tiedje. 1994. Isolation and characterization of a novel bacterium growing via reductive dehalogenation of 2-chlorophenol. Appl. Environ. Microbiol. 60: 3536-3542.

Cupples A.M., R.A. Sanford and G.K. Sims. 2005. Dehalogenation of the herbicides bromoxynil (3,5-dibromo-4-hydroxybenzonitrile) 
and ioxynil (3,5-diiodino-4-hydroxybenzonitrile) by Desulfitobacterium chlororespirans. Appl. Environ. Microbiol. 71: 3741-3746.

Deweerd K.A., L. Mandelco, R.S. Tanner, C.R. Woese and J.M. Suflita. 1990. Desulfomonile tiedjei gen. nov. and sp. nov., a novel anaerobic, dehalogenating, sulfate-reducing bacterium. Arch. Microbiol. 154: 23-30.

Drzyzga O., J. Gerritse, J.A. Dijk, H. Elissen and J.C. Gottschal. 2001. Coexistence of a sulphate-reducing Desulfovibrio species and the dehalorespiring Desulfitobacterium frappieri TCE1 in defined chemostat cultures grown with various combinations of sulfate and tetrachloroethene. Environ. Microbiol. 3(2): 92-99.

Duhamel M. and E.A. Edwards. 2007. Growth and yields of dechlorinators, acetogens, and methanogens during reductive dechlorination of chlorinated ethenes and dihaloelimination of 1,2-dichloroethane. Environ. Sci. Technol. 41: 2303-2310.

El Fantroussi S., H. Naveau and S.N. Agathos. 1998. Anaerobic dechlorinating bacteria. Biotechnol. Prog. 14: 167-188.

Fagervold S.K., J.E.M. Watts, H.D. May and K.R. Sowers. 2005 Sequential reductive dechlorination of meta-chlorinated polychlorinated biphenyl congeners in sediment microcosms by two different Chloroflexi phylotypes. Appl. Environ. Microbiol. 71(12): 8085-8090. Fennell D.E., V. Nijenhuis, S.F. Wilson, S.H. Zinder and M.M. Häggblom. 2004. Dehalococcoides ethenogenes strain 195 reductively dechlorinates diverse chlorinated aromatic pollutants Environ. Sci. Technol. 38: 2075-2081.

Fung J.M., B.P. Weisenstein, E.E. Mack, J.E. Vidumsky, T.A. Ei and S.H. Zinder. 2009. Reductive dehalogenation of dichlorobenzenes and monochlorobenzene to benzene in microcosms. Environ. Sci. Technol. 43: 2302-2307.

Gauthier A., R. Beaudet, F. Le' pine, P. Juteau and R. Villemur 2006. Occurrence and expression of crdA and cprA5 encoding chloroaromatic reductive dehalogenases in Desulfitobacterium strains. Can. J. Microbiol. 52(1): 47-55.

Gelsomino A., C. Keijzer-Wolters, G. Cacco and J.D. van Elsas. 1999. Assessment of bacterial community structure in soil by poly merase chain reaction and denaturing gradient gel electrophoresis. J. Microbiol. Methods 38: 1-15.

Gerritse J., V. Renard, P.T.M. Gomes, P.A. Lawson, M.D. Collins and J.C. Gottschal. 1996. Desulfitobacterium sp. strain PCE1, an anaerobic bacterium that can grow by reductive dechlorination of tetrachloroethene or ortho-chlorinated phenols. Arch. Microbiol. 165(2): 132-40.

Gerritse J., O. Drzyzga, G. Kloetstra, M. Keijmel, L.P. Wiersum R. Hutson, M.D. Collins and J.C. Gottschal. 1999. Influence of different electron donors and acceptors on dehalorespiration of tetrachloroethene by Desulfitobacterium frappieri TCE1. Appl. Environ. Microbiol. 65(12): 5212-5221.

Häggblom M.M. 1992. Microbial breakdown of halogenated aromatic pesticides and related compounds. FEMS Microbiol. Rev. 103: 29-71. Häggblom M.M. and I.G. Bossert (eds). 2003. Dehalogenation, microbial processes and environmental applications. Kluwer Academic Publisher Group, Norwell, MA.

Holliger C., G. Wohlfarth and G. Diekert. 1998. Reductive dechlorination in the energy metabolism of anaerobic bacteria. FEMS Microbiol. Rev. 22: 383-398.

Holliger C., C. Regeard and G. Diekert. 2003. Dehalogenation by anaerobic bacteria, pp. 115-157. In: Häggblom M.M. and I.D. Bossert (eds). Dehalogenation, Microbial Processes and Environmental Applications. Kluwer Academic Publisher Group, Norwell, MA.

Hug L.A. 2012. Ph.D. Thesis. A metagenome-based examination of dechlorinating enrichment cultures: Dehalococcoides and the role of the non-dechlorinating microorganisms, pp. 1-264. Cell and Systems Biology, University of Toronto, Canada.

Hug L.A. and E.A. Edwards. 2013. Diversity of reductive dehalogenase genes from environmental samples and enrichment cultures identified with degenerate primer PCR screens. Front. Microbiol. 49(341): 1-16.

Hug L.A., F. Maphosa, D. Leys, F.E. Löffler, H. Smidt, E.A. Edwards and L. Adrian. 2013. Overview of organohalide-respiring bacteria and a proposal for a classification system for reductive dehalogenases. Phil. Trans R. Soc. B. 368: 20120322.

Itoh K., Y. Mihara, N. Tanimoto, T. Shimada and K. Suyama. 2010. Reductive dechlorination of chlorophenols in estuarine sediments of Lake Shinji and Lake Nakaumi. J. Environ. Sci. Health B. 45(5): 399-407.

Karn S.K., S.K. Chakrabarti and M.S. Reddy. 2011. Degradation of pentachlorophenol by Kocuria sp. CL2 isolated from secondary sludge of pulp and paper mill. Biodegradation 22: 63-69.

Kjellerup B.V., C. Naff, S.J. Edwards, U. Ghosh, J.E. Baker and K.R. Sowers. 2014. Effects of activated carbon on reductive dechlorination of PCBs by organohalide respiring bacteria indigenous to sediments. Water Res. 52: 1-10.

Kumar S., K. Tamura and M. Nei. 2004. MEGA3: An integrated software for Molecular Evolutionary Genetics Analysis and sequence alignment. Brief Bioinform. 5: 150-163.

Kuokkaa S., A.L. Rantalainena, M. Romantschuka and M.M. Häggblom. 2014. Effect of temperature on the reductive dechlorinationof 1,2,3,4-tetrachlorodibenzofuran in anaerobicPCDD/Fcontaminated sediments. J. Haz. Mat. 274: 72-78.

Lake J.L., R.J. Pruell and F.A. Osterman. 1992. An examination of dechlorination processes and pathways in New Bedford Harbor sediments. Mar. Environ. Res. 33: 31-47.

Leys D., L. Adrian and H. Smidt. 2013. Organohalide respiration: microbes breathing chlorinated molecules. Phil. Trans R. Soc. B. 368: 20120316.

Li Z., Y. Inoue, D. Suzuki, L. Ye and A. Katayama. 2013. Long-term anaerobic mineralization of pentachlorophenol in a continuous-flow system using only lactate as an external nutrient. Environ. Sci. Technol. 47: 1534-1541.

Löffler F.E., R.A. Sanford and J.M. Tiedje. 1996. Initial characterization of a reductive dehalogenase from Desulfitobacterium chlororespirans Co23. Appl. Environ. Microbiol. 62: 3809-3813.

Löffler F.E., J.R. Cole, K.M. Ritalahti and J.M. Tiedje. 2003. Diversity of dechlorinating bacteria. Dehalogenation, pp. 53-87. In: Häggblom M.M. and I.D. Bossert (eds). Microbial processes and environmental applications. Kluwer Academic Publisher Group, Norwell, MA.

Luijten M., W. Roelofsen, A.A.M. Langenhoff, G. Schraa and A.J.M. Stams. 2004. Hydrogen threshold concentrations in pure cultures of halorespiring bacteria and at a site polluted with chlorinated ethenes. Environ. Microbiol. 6: 646-650.

Madsen T. and D. Licht. 1992. Isolation and characterization of an anaerobic chlorophenol-transforming bacterium. Appl. Environ. Microbiol. 58:2874-2878.

Maphosa F., M.W.J. van Passel, W.M. de Vos and H. Smidt. 2012. Metagenome analysis reveals yet unexplored reductive dechlorinating potential of Dehalobacter sp. E1 growing in co-culture with Sedimentibacter sp. Environ. Microbiol. Rep. 4: 604-616.

Masunaga S., S. Susarla, J.L. Gundersen and Y. Yonezawa. 1996. Pathways and rate of chlorophenol transformation in anaerobic estuarine sediment. Environ. Sci. Technol. 30: 1253-1260.

Maymo-Gatell X., Y.T. Chien, J.M. Gossett and S.H. Zinder. 1997. Isolation of a bacterium that reductively dechlorinates tetrachloroethene to ethene. Science 276: 1568-1571.

Mazur C.S. and W.J. Jones. 2001. Hydrogen concentrations in sulfate-reducing estuarine sediments during PCE dehalogenation. Environ. Sci. Technol. 35: 4783-4788.

Mazur C.S., W.J. Jones and C.T. Stevens. 2003. $\mathrm{H}_{2}$ consumption during the microbial reductive dehalogenation of chlorinated phenols and tetrachloroethene. Biodegradation 14:(4) 285-295. 
McAllister K.A., H. Lee and J.T. Trevors. 1996. Microbial degradation of pentachlorophenol. Biodegradation 7: 1-40.

Muyzer G., E. de Waal and A. Uitterlinden. 1993. Profiling of complex microbial populations by denaturing gradient gel electrophoresis analysis of polymerase chain reaction-amplified genes coding for 16S rRNA. Appl. Environ. Microbiol. 59: 695-700.

Rowe A.R., B.J. Lazar, R.M. Morris and R.E. Richardson. 2008. Characterization of the community structure of a dechlorinating mixed culture and comparisons of gene expression in planktonic and biofloc-associated Dehalococcoides and Methanospirillum species. Appl. Environ. Microbiol. 74: 6709-6719.

Saitou N. and M. Nei. 1987. The neighbor-joining method: a new method for reconstructing phylogenetic trees. Mol. Biol. Evol. 4: 406-425.

Sanford R.A., J.R. Cole, F.E. Löffler and J.M. Tiedje. 1996. Characterization of Desulfitobacterium chlororespirans sp. nov., which grows by coupling the oxidation of lactate to the reductive dechlorination of 3-chloro-4-hydroxybenzoate. Appl. Environ. Microbiol. 62: 3800-3808.

Sanford R.A., J.R. Cole and J.M. Tiedje. 2002. Characterization and description of Anaeromyxobacter dehalogenans gen. nov., sp. nov., an aryl-halorespiring facultative anaerobic myxobacterium. Appl. Environ. Microbiol. 68: 893-900.

Sanger F., S. Nicklen and A.R. Coulson. 1977. DNA sequencing with chain-termination inhibitors. Proc. Natl. Acad. Sci. USA 74: 5463-5467.

Smidt H., M. van Leest, J. van der Oost and W.M. de Vos. 2000. Transcriptional regulation of the cpr gene cluster in ortho-chlorophenol-respiring Desulfitobacterium dehalogenans. J. Bacteriol. 182(20): 5683-5691.

Smidt H. and W.M. de Vos. 2004. Anaerobic microbial dehalogenation. Annu. Rev. Microbiol. 58: 43-73.

Sun B., J.R. Cole, R.A. Sanford and J.M. Tiedje. 2000. Isolation and characterization of Desulfovibrio dechloracetivorans sp. nov., a marine dechlorinating bacterium growing by coupling the oxidation of acetate to the reductive dechlorination of 2 chlorophenol. Appl. Environ. Microbiol. 66(6): 2408-2413.

Takeuchi R., Y. Suwa, T. Yamagishi and Y. Yonezawa. 2000. Anaerobic transformation of chlorophenols in methanogenic sludge unexposed to chlorophenols. Chemosphere 41:1457-1462.

Thibodeau J., A. Gauthier, M. Duguay, R. Villemur, F. Le'pine, P. Juteau and R. Beaudet. 2004. Purification, cloning, and sequencing of a 3,5-dichlorophenol reductive dehalogenase from Desulfitobacterium frappieri PCP-1. Appl. Environ. Microbiol. 70: 4532-4537. Thomas S.H., R.D. Wagner, A.K. Arakaki, J. Skolnick, J.R. Kirby, L.J. Shimkets, R.A. Sanford and F.E. Löffler. 2008. The mosaic genome of Anaeromyxobacter dehalogenans strain 2CP-C suggests an aerobic common ancestor to the delta-proteobacteria. PLoS ONE 3(5): e2103.

Thompson D., J. Gibson, F. Plewinak, F. Jeanmougin and G. Higgins. 1997. The Clastal X windows interface: flexible strategies for multiple sequence alignment aided by quality analysis tools. $N u c$. Acid Res. 25: 4867-4887.
Utkin I., C. Woese and J. Wiegel. 1994. Isolation and characterization of Desulfitobacterium dehalogenans gen. nov., sp. nov., an anaerobic bacterium which reductively dechlorinates chlorophenolic compounds. Int. J. Syst. Bacteriol. 44: 612-619.

van de Pas B.A., H. Smidt, W.R. Hagen, J. van der Oost, G. Schraa, A.J. Stams and W.M. de Vos. 1999. Purification and molecular characterization of ortho-chlorophenol reductive dehalogenase, a key enzyme of halorespiration in Desulfitobacterium dehalogenans. J. Biol. Chem. 274: 20287-20292.

Vandermeeren P., S. Herrmann, D. Cichocka, P. Busschaert, B. Lievens, H.H. Richnow and D. Springael. 2014. Diversity of dechlorination pathways and organohalide respiring bacteria in chlorobenzene dechlorinating enrichment cultures originating from river sludge. Biodegradation. 25(5): 757-776.

von Wintzingerode F., C. Schlötelburg, R. Hauck, W. Hegemann and U.B. Göbel. 2001. Development of primers for amplifying genes encoding CprA- and PceA-like reductive dehalogenases in anaerobic microbial consortia, dechlorinating trichlorobenzene and 1,2-dichloropropane. FEMS Microbiol. Ecol. 35: 189-196.

Villemur R., M. Saucier, A. Gauthier and R. Beaudet. 2002 Occurrence of several genes encoding putative reductive dehalogenases in Desulfitobacterium hafnienselfrappieri and Dehalococcoides ethenogenes. Can. J. Microbiol. 48(8): 697-706.

Villemur R., M. Lanthier, R. Beaudet and F. L'epine. 2006. The Desulfitobacterium genus FEMS Microbiol. Rev. 30:706-733. Villemur R. 2013. The pentachlorophenol-dehalogenating Desulfitobacterium hafniense strain PCP-1. Philos. Trans R. Soc. B. 368(1616) 20120319.

Wagner D.D., L.A. Hug, J.K. Hatt, M.A. Spitzmiller, E. PadillaCrespo, K.M. Ritalahti, E.A. Edward, K.T. Konstantinidis and F.E. Löffler. 2012. Genomic determinants of organohalide-respiration in Geobacter lovleyi, an unusual member of the Geobacteraceae. BMC Genomics 13(200): 1-17.

Wang S., W. Zhang, K.L. Yang and J. He. 2014. Isolation and characterization of a novel Dehalobacter species strain TCP1 that reductively dechlorinates 2,4,6-trichlorophenol. Biodegradation. 25(2): 313-323.

WHO. 1998. Guidelines for Drinking-Water Quality, $2^{\text {nd }}$ eds. Addendum to Vol. 1, Recommendations, pp. 21-22. World Health Organization, Geneva.

WHO. 1989. Chlorophenols other than pentachlorophenol. World Health Organization, Geneva.

Wiegel J., X.M. Zhang and Q.Z. Wu. 1999. Anaerobic dehalogenation of hydroxylated polychlorinated biphenyls by Desulfitobacterium dehalogenans. Appl. Environ. Microbiol. 65: 2217-2221.

Wu Q.Z., K.R. Sowers and H.D. May. 1998. Microbial reductive dechlorination of Aroclor 1260 in anaerobic slurries of estuarine sediments. Appl. Environ. Microbiol. 64: 1052-1058.

Zanaroli G., A. Balloi, A. Negroni, D. Daffonchio, L.Y. Young and F. Fava. 2010. Characterization of the microbial community from the marine sediment of the Venice lagoon capable of reductive dechlorination of coplanar polychlorinated biphenyls (PCBs). J. Haz. Mat. 178: 417-426. 